Marquette University

e-Publications@Marquette

Finance Faculty Research and Publications

Finance, Department of

$1-1-1995$

\title{
A Descriptive Analysis of U.S. Housing Demand for the $1990 \mathrm{~s}$
}

Mark Eppli

Marquette University, mark.eppli@marquette.edu

Monty J. Childs

Kenneth Leventhal \& Company

Published version. Journal of Real Estate Research, Vol. 10, No. 1 (1995): 69-86. Publisher Link. (C) 1995 American Real Estate Society. Used with permission.

Mark Eppli was affiliated with George Washington University at the time of publication. 


\title{
A Descriptive Analysis of U.S. Housing Demand for the 1990s
}

\begin{abstract}
We analyze the effect of changes in type of household formation (i.e., single person, single parent, married couple, etc.) on the demand for housing and segment income by household type to determine housing tenure. Using data disaggregated by household type, we forecast housing demand for the United States through the turn of the century. The results indicate that total housing demand for the decade will be 11.8 million units, of which 8.1 million will be owner-occupied and 3.7 million will be renter-occupied.
\end{abstract}

\section{Introduction}

When estimating long-term demand for housing, simplicity of method should be praised unless biases in the forecasts are produced. Biases in many housing demand forecasts are introduced by using static population per household figures and average household income numbers to determine the quantity and type of housing demanded. The purpose of this paper is to estimate housing demand in the 1990s by evaluating both demographic and socioeconomic changes in the demand for housing. ${ }^{1}$ In particular, we analyze the effect of changes in type of household formation on housing demand. The results of this research can be directly used by real estate professionals to estimate multifamily and single-family housing demand.

The paper consists of five sections. In the next section, we assess the impact of changes in the 25-34 age cohort, net immigration, and population reductions on household formation. Changes in population per household (household size) are analyzed in section three. The fourth section, Household Income and Housing Tenure, evaluates the changing socioeconomic influences on the housing market and estimates the demand for owner-occupied and renter-occupied housing in the 1990s. The paper is summarized in section five.

\section{Demographics and Household Formation}

As demographers have shown in the literature, a large proportion of new households are created by the 25-34-year-old age cohort. ${ }^{2}$ Household formation is also affected by net immigration to the U.S. Reductions in population from death are also necessary to determine net household formation.

\section{Segmenting the Population by Age Cohort}

The first step in estimating household formation is to disaggregate the population by age cohort. The need to disaggregate demographic data has broad precedence in the

\footnotetext{
*Department of Finance, George Washington University, 2023 G Street, NW, Washington, DC, 20052.

**Kenneth Leventhal \& Company, 1 N. Franklin Street, Chicago, Illinois 60606.

Date Revised-November 1994; Accepted-November 1994.
} 
literature. ${ }^{3}$ Exhibit 1 projects the percentage change in resident population by age cohort in five-year time increments from 1990-2020. Highlighted in bold in Exhibit 1 are the age cohorts that will create a majority of the households over the decade of the 1990s. These three age cohorts (20-24, 25-29, and 30-34) are also generally defined as the Generation $X$ cohort ${ }^{4}$ As Generation X moves through the 1990s, this popular-press-defined cohort will increase in age from 12-26 years old in 1990 to 22-36 years old in year 2000.

For the past two decades, the baby boom generation was the engine behind demand driven increase in housing prices. During the household formation years of the baby boom generation (1971-1989), 27.6 million new households were formed. ${ }^{5}$ In 1995, the baby boom generation, which includes the 72 million people born between 1946-1964, will be 31-49 years old, and in most cases will have formed households separate from their parent's household. Additionally, since the average age of the first-time homeowner was 30.6 in 1992, a majority of the baby boom generation will also have been absorbed into the owner-occupied housing market. ${ }^{6}$ As the baby boom generation is now beyond the point where it creates new households, Generation X currently is the primary force behind new housing demand.

Demographically Generation X, which is currently between the ages of 17 and 30, is very different from the baby boom generation that preceded it. The total population of 25-34-year-old cohort in 1991, which includes the last of the baby boom generation, was

\section{Exhibit 1}

Percentage Change in the Age Composition of the U.S. Population, 1990-2020

\begin{tabular}{|c|c|c|c|c|c|c|}
\hline \multirow[b]{2}{*}{$\begin{array}{c}\text { Age } \\
\text { Group }\end{array}$} & \multicolumn{6}{|c|}{ Time Period } \\
\hline & $\begin{array}{c}1990- \\
1995\end{array}$ & $\begin{array}{l}1995- \\
2000\end{array}$ & $\begin{array}{l}2000- \\
2005\end{array}$ & $\begin{array}{c}2005- \\
2010\end{array}$ & $\begin{array}{c}2010- \\
2015\end{array}$ & $\begin{array}{c}2015- \\
2020\end{array}$ \\
\hline Under 5 & -3.3 & -5.1 & -1.7 & 1.7 & 1.9 & -.7 \\
\hline $5-9$ & 2.1 & -3.4 & -5.0 & -1.7 & 1.7 & 1.8 \\
\hline $10-14$ & 9.0 & 1.9 & -3.3 & -4.9 & -1.6 & 1.7 \\
\hline $15-19$ & .9 & 8.8 & 1.9 & -3.3 & -4.9 & -1.6 \\
\hline $20-24$ & -6.5 & .7 & 8.6 & 1.8 & -3.3 & -4.7 \\
\hline $25-29$ & -11.8 & -6.5 & .5 & 8.4 & 1.7 & -3.1 \\
\hline $30-34$ & -1.9 & -11.7 & -6.4 & .5 & 8.2 & 1.7 \\
\hline $35-39$ & 10.0 & -1.9 & -11.7 & -6.4 & .4 & 8.1 \\
\hline $40-44$ & 13.7 & 10.0 & -1.9 & -11.7 & -6.4 & .5 \\
\hline $45-49$ & 25.4 & 13.7 & 10.0 & -1.8 & -11.7 & -6.4 \\
\hline $50-54$ & 19.7 & 25.6 & 13.8 & 10.1 & -1.8 & -11.5 Generation X \\
\hline $55-59$ & 5.7 & 19.9 & 25.7 & 13.8 & 10.1 & -1.8 \\
\hline $60-64$ & -6.0 & 6.0 & 20.1 & 25.9 & 13.9 & 10.1 \\
\hline $65-69$ & -1.9 & -5.6 & 6.5 & 20.4 & 26.0 & 14.0 \\
\hline $70-74$ & 9.3 & -1.4 & -5.1 & 6.9 & 20.6 & 26.2 \\
\hline $75-79$ & 8.2 & 10.2 & -.5 & -4.6 & 7.3 & 21.1 \\
\hline $80-84$ & 12.7 & 9.7 & 11.7 & .2 & -4.3 & 7.8 \\
\hline 85 and over & 20.2 & 18.1 & 15.4 & 14.7 & 7.3 & 1.4 \\
\hline All ages & 3.9 & 3.1 & 2.7 & 2.5 & 2.3 & 1.9 \\
\hline
\end{tabular}

Source: Plane and Rogerson (1991), p. 419

VOLUME 10, NUMBER 1, 1995 
42,905,000 people. $^{7}$ In 1991, the 15-24-year-old age cohort, which encompasses a majority of the Generation $X$ age cohort, included $34,825,000$ people. ${ }^{8}$ The $8,080,000$ person decline between the 1980s 25-34 age cohort and the 1990s forthcoming 25-34 age cohort portends a decrease in the number of household formations.

\section{Net Immigration to the United States}

Immigration to the United States is affected by both government policy and unmanaged migration. While the net immigration of foreigners to the United States is not a dominant force on housing demand in the U.S., the impact of this group is growing. Passage of the Immigration Act of 1990 increases legal immigration quotas by about $30 \%$ from 540,000 to 700,000 per year. ${ }^{9}$ Many of these immigrant slots are allocated to reunify families. An additional 140,000 slots are reserved for skill-based, employer-sponsored immigrants. ${ }^{10}$ Meanwhile, the number of illegal immigrants is expected to continue at approximately $200,000-250,000$ people per year. ${ }^{11}$

The ethnic composition of legal immigrants to the U.S. also has changed considerably over the past thirty years. The predominantly white and black population of the United States has become more heterogeneous due to a dramatic increase in the percentage of Asian and Hispanic immigrants. During the 1950 s, a total of $31 \%$ of the net immigration to the U.S. was from Asia, Latin America and South America, while 53\% of all immigrants were from Europe (see Exhibit 2). Net immigration to the U.S. from Asia and Latin and South America more than doubled from 1950 to 1990, while net immigration from Europe fell to $10 \%$ of net immigration. Not included in Exhibit 2 are illegal immigrants. Most illegal immigrants are from Latin American countries, making the proportion of immigrants from Latin America even larger.

Annual net immigration to the U.S. is expected to increase from 900,000 in 1990 to 950,000 in year 2005 , with a total estimate of $9,250,000$ immigrants during the $1990 \mathrm{~s} .{ }^{12}$ Of the legal immigrants (approximately 7,000,000 people), the number of Asian and East European immigrants is expected to increase based on the increase in skill-based, employer-sponsored immigrant slots. The number of legal immigrants from Latin America and South America is expected to decline slightly due to recent increases in real wage rates in these regions. For a longitudinal assessment of net immigration to the U.S., see Exhibit 3.

\section{Reductions in Population}

Between 1970 and 1990 the average annual death rate per year has been $1,998,238$, with a range of $1,893,000$ to 2,168,000. ${ }^{13}$ As can be seen in Exhibit 4, the death rate in the U.S. has been stable over the past twenty years with a slight increase over time. Since 1982 , the average death rate per year has been $2,094,000$, with a range of $2,019,000$ to $2,168,000$.

During the decade of the 1990s, Exhibit 1 reveals that the population is generally declining in the 60-69 age cohorts, but the $70+$ age cohorts are expecting significant growth. Although the growth rate for the $70+$ age cohorts is much larger than the expected decline in the 60-69 age cohorts, the absolute number of persons in the 60-69 age cohorts is substantially larger than the $70+$ age cohorts. Based on the mortality rates and the size of these cohorts, the aggregate death rate is expected to grow at a rate that is consistent with the growth in total deaths over the past several decades. The average 


\section{Exhibit 2}

Net Immigration to the United States by Continent of Origin, 1951-2000 (in percent)

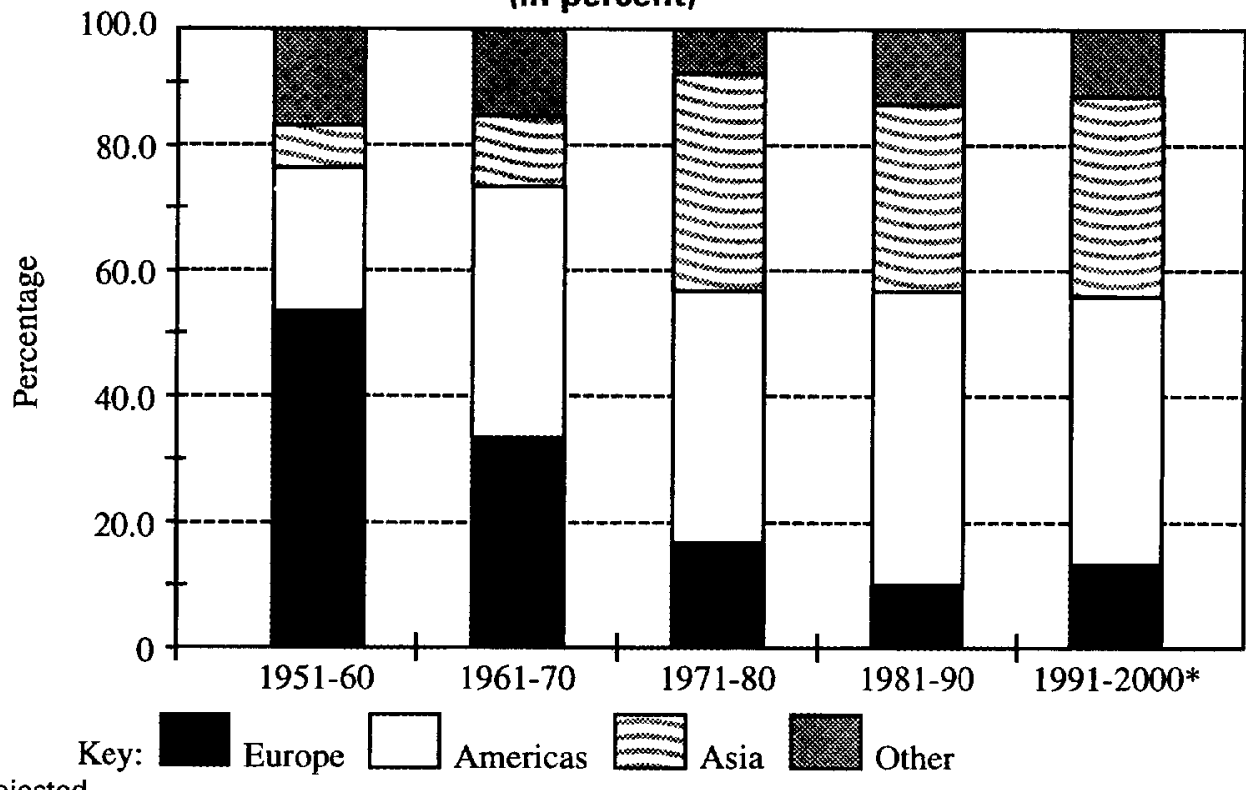

* projected

Source: Information Please Almanac (1994), p. 829

\section{Exhibit 3}

Net Immigration to the U.S., 1951-2000

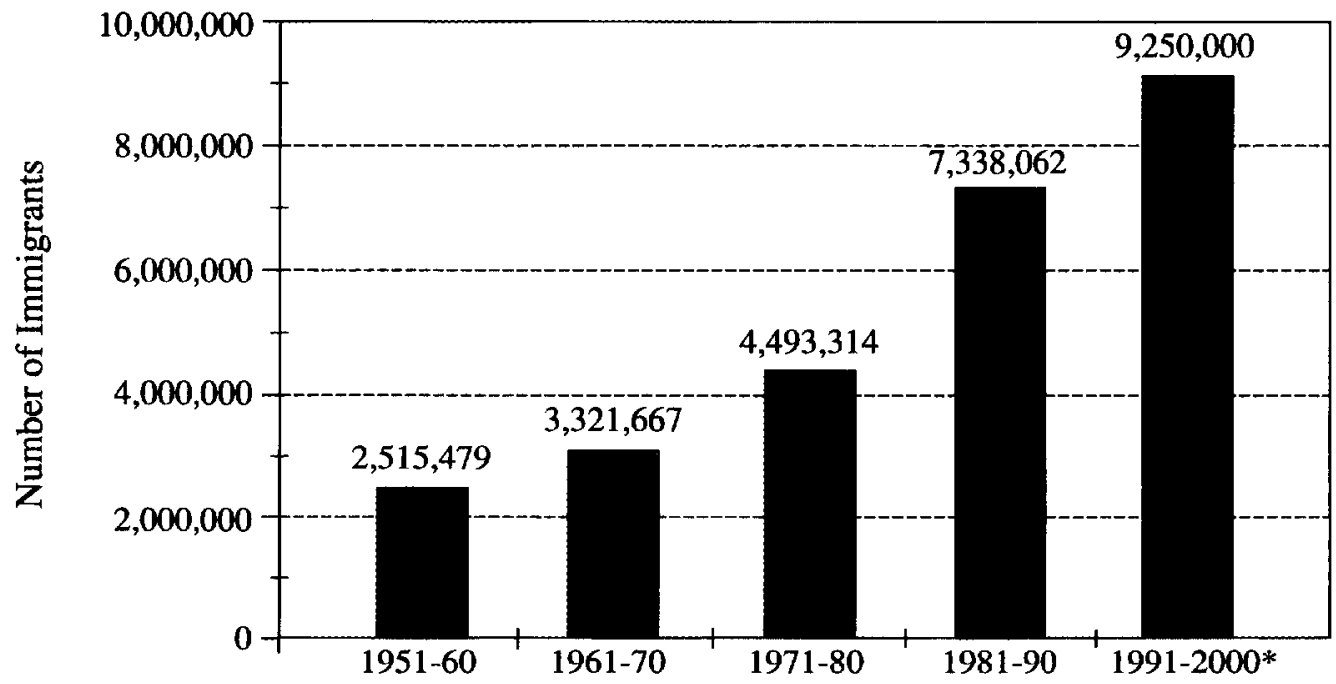

${ }^{*}$ projected

Source: Information Please Almanac (1994), p. 829

VOLUME 10, NUMBER 1, 1995 


\section{Total Deaths in the U.S., 1960-2000}

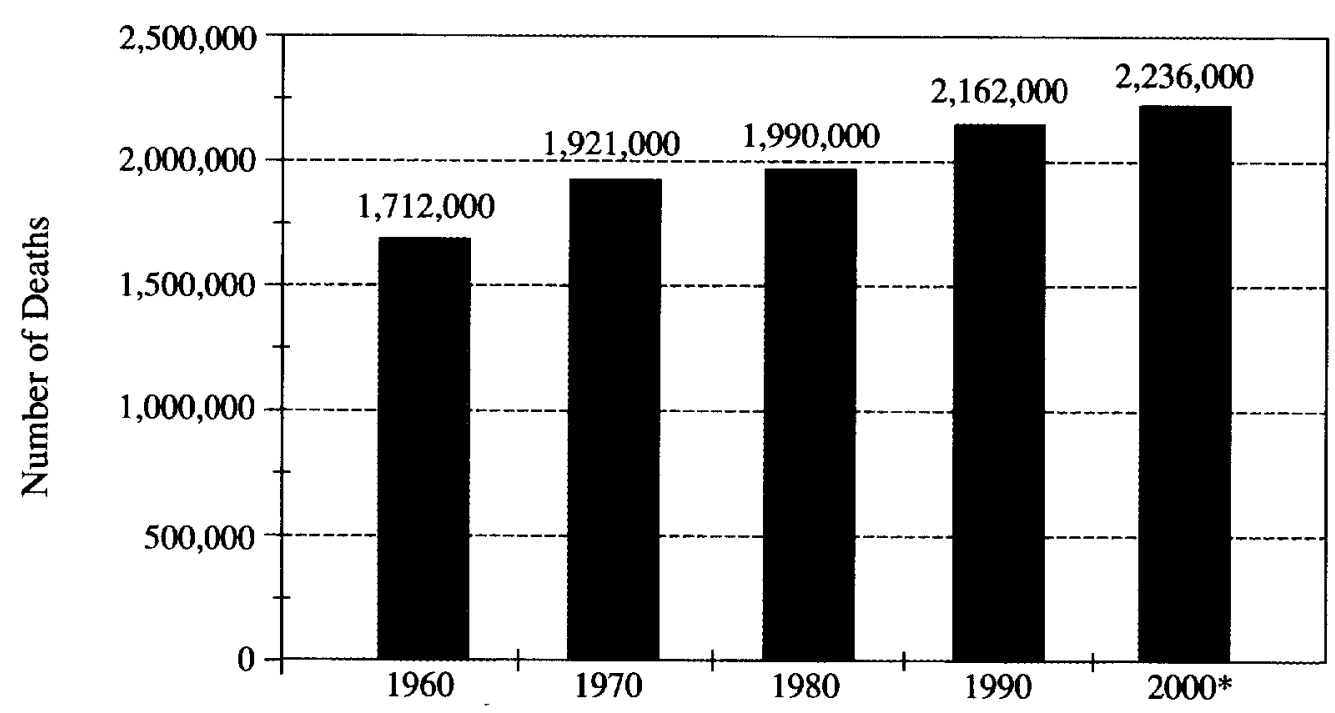

*projected

Source: U.S. Bureau of the Census, Statistical Abstract (1990), p. 64

annual death rate in the 1990 s is expected to be $2,163,000$ people per year, with a projected annual death rate in year 2000 of $2,236,000$.

\section{Estimating Housing Demand}

The first step in assessing housing demand is to estimate the net increase in population for the young adult age cohorts. There were $34,825,000$ people in the $15-24$ age cohort in 1991, which will constitute the household formation age cohort for the rest of the 1990s. Additions to the population from net immigration during the decade are expected to add another $9,250,000$ people. The reduction in the population from death is expected to total $21,630,000$ for the decade. Thus, the total net change in the population that either forms new households or reduces the number of households is projected to be $22,445,000$ people during the 1990s.

\section{Changes in Population per Household (Household Size)}

Approximately $50 \%$ of the households formed between 1971 and 1989 were attributable to a reduction in average household size. Since the early $1960 \mathrm{~s}$, there has been a steady reduction in average population per household from 3.33 people per household in 1960 to 2.62 people per household in 1992 (see Exhibit 5). Population per household is dependent on several factors. First, lower birth rates have reduced family size over the past several decades. For example, the birth rate per thousand population fell from 24.1 in 1950 , in the height of the baby boom, to 14.6 in 1975 during the low birth rates of the 


\section{Exhibit 5}

\section{Average Population per Household (Household Size), 1960-1992}

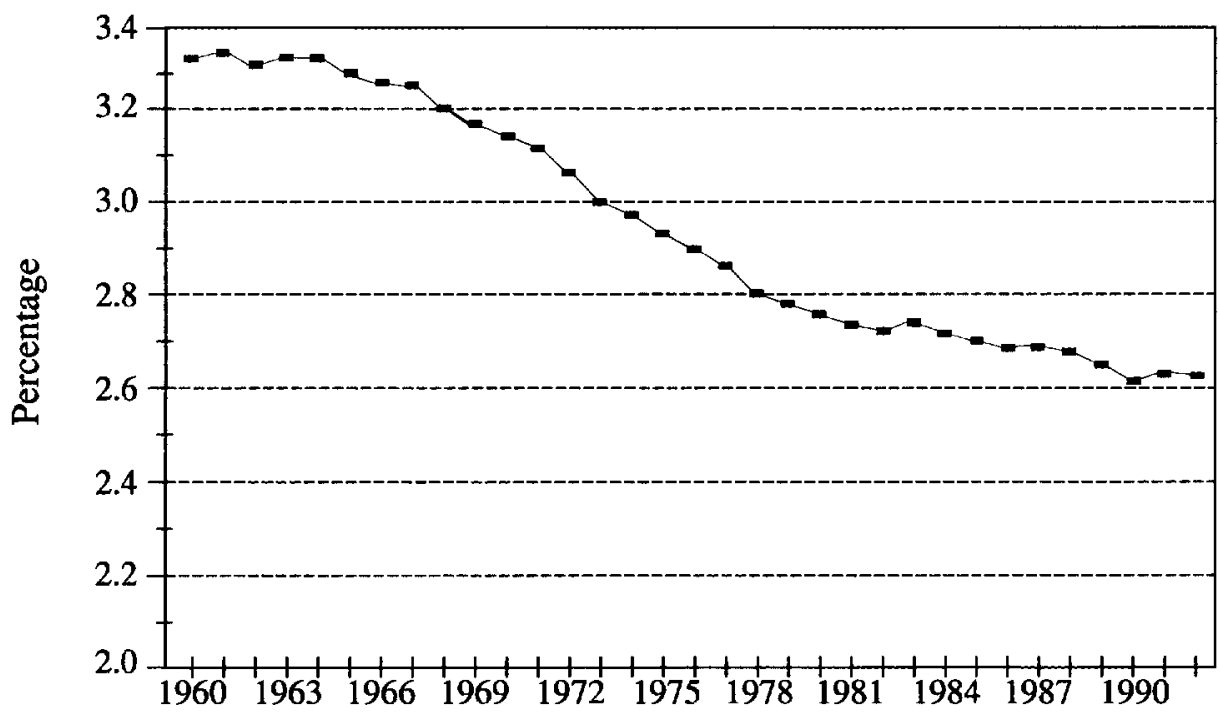

Source: U.S. Bureau of the Census (1991), Table A-1

Generation X birth years. ${ }^{14}$ Although the baby boom echo infants of the 1990 s will increase the average population per household, they will have little effect on the creation of new households in the 1990s as they only enlarge existing households. Therefore, what must be analyzed are changes in the population per household for those persons who are currently forming or extinguishing households.

\section{Household Formation by Young Adults ${ }^{15}$}

Young adult household formation can be segmented into four census-defined categories: (1) family householder, (2) non-family householder, (3) child of householder, and (4) other. Family householder includes all married couple households and single parent households. Non-family households are single person households and two or more unrelated person households. Child of householder includes all 25-34-year-old individuals who live with their parents. The other category is the residual. Exhibit 6 gives a historical view of the living arrangements of the 25-34-year-old U.S. resident adults.

Family households, in particular married couple households, historically have been considered the population segment that demands owner-occupied housing more than any other group. Based on the U.S. Bureau of the Census (May 1993), the number of 25-34year-old family households has steadily declined over the past several decades from $83 \%$ in 1960 to $65 \%$ in 1990 . The second category delineated in Exhibit 6 is the non-family young adult households. The non-family segment remained relatively small between 1960 and 1970 at approximately $3 \%-5 \%$ of the cohort's population, but increased in size dramatically to $12 \%$ in 1980 and to $13 \%$ in 1990 . The child of a householder category 


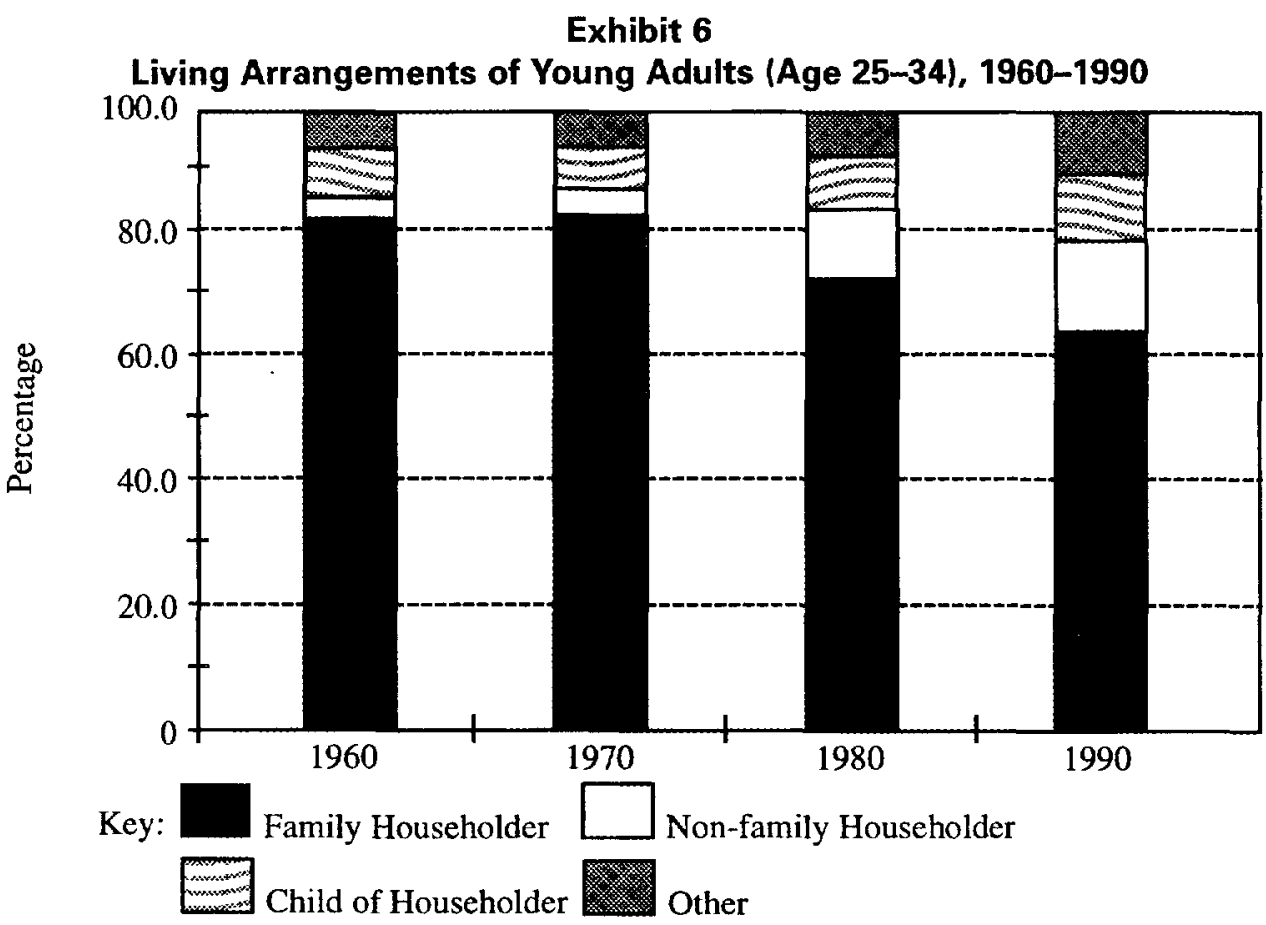

Source: U.S. Bureau of the Census (May 1993)

remained steady at $9 \%$ between 1960 and 1980 , but in 1990 this percentage climbed to $12 \%$.

In $1990,57 \%$ of the $25-34$ family householder category were married couple households and $8 \%$ were single parent households. ${ }^{16}$ The population per household for married couple households is 2.00 , and the population per household for single parent households is $1.00 .^{17}$ Ten percent of the non-family households are single person households demanding a household for each person in the category. The remaining nonfamily households and other households total $13 \%$ of the population, which can be broadly defined as two or more unrelated individual households. Based on 1991 U.S. Census data, for two or more unrelated individual households, $81 \%$ are two-person households, $13 \%$ are three-person households, $4 \%$ are four-person households, and less than $2 \%$ are five-or-more-person households. ${ }^{18} \mathrm{~A}$ weighted average estimate of population per household for non-family households with two or more people is 2.29 . Children of householders, which includes $12 \%$ of the 25-34 age cohort, create no additional households while they are in this category.

Although young adults living with their parents do not create a new household while they are in the 25-34 age cohort, U.S. Census data shows that most do create new households during the decade that follows. ${ }^{19}$ Little research to date has addressed the type of household young adults living with their parents eventually form. We estimate the population per household for young adults living with their parents lagged by ten years to be 1.83, using a weighted average of the married couple, single person, single parent, and two or more unrelated people living together categories. 


\section{Net Immigration Household Formation}

Household size for the immigrant population is difficult to determine. Carliner (1990) estimates that immigrants admitted as "professionals of exceptional ability" will have an average household size of 2.0 to 2.5. Based on the Immigration Act of 1990, the number of immigrants admitted under the exceptional ability category and the skill-based, employer-sponsored categories is 140,000 people per year. At the other end of the spectrum, spouses and minor children of residents (about 160,000 per year) have a smaller impact on housing demand. Reuniting families do create new households as the spouse that immigrated earlier moves out of a group housing arrangement and in with his/her family or extended family. Thus, for every fourth family reunification immigrant, we assume a new household is created. According to the U.S. Bureau of the Census (1990), the median household size for Hispanic families was 3.38 in 1989 . We use this number as the best estimate of population per household for the legal immigrants that are not in the employer-sponsored, family reunification, and illegal immigrant categories.

Illegal immigration is expected to account for 225,000 immigrants per year in the 1990 s. Based on an analysis of the relevant literature, our best estimate of population per household for this group is 5.0. Another area of household formation for immigrant population is a lag factor for the change in household size, as multiple family living arrangements in group housing find nuclear family housing in the decade after immigrating. After residing in the U.S. for approximately a decade, legal immigrants become more financially stable and move to nuclear family settings, thus reducing the average legal immigrant household from 3.5 to 3.0 , or by .5 persons per household.

\section{Reduction in Households Due to Death}

According to the U.S. Bureau of the Census, elderly citizens live in one of three mutually exclusive categories: alone, with spouse, or with other relatives or non-relatives. For all people 65 years old and over, $31 \%$ live alone, $54 \%$ live with a spouse, and $15 \%$ live with other relatives or non-relatives. ${ }^{20}$ We assume that citizens 65 years old and over who live alone reduce the number of households by one upon death, married couples reduce the number of households by .5 for each death, and persons who live with other relatives and non-relatives do not affect the number of households upon death. Based on these household size assumptions, the weighted average population per household is 1.39 for the age $65+$ age cohorts.

\section{Net Household Formation in the 1990s}

The net change in household formation in the 1990s is a function of two broad factors: shifts in the population and changes in population per household. These demographic and societal changes are expected to create approximately 11.8 million households during the decade of the 1990s, which is calculated in Exhibit 7.

The first subcategory in Exhibit 7 is young adult household formation, segmented by household type. Information in columns (a) and (b) of Exhibit 7 are based on Exhibits 1 and 6. Using trends established in Exhibit 6, the married couple household category in Exhibit 7 is expected to decline from $57 \%$ in 1990 to $53 \%$ in 2000 , with the other household types expected to increase in size proportionally. Population per household for the 25-34 age cohort, column (d) of Exhibit 7, is determined with near certainty as married 
couple households have two young adults per household, while single person and single parent households include one young adult per household. The 2.29 population per household for two or more unmarried, young adults living together is a weighted average of census data.

Children of householders do not form new households while in the 25-34 age cohort, but in most situations form a household when they enter the 35-44 age cohort. We expect that people per household for the child of householder category lagged by ten years can

Exhibit 7

Net Household Formation in the United States, 1990-2000*

\begin{tabular}{|c|c|c|c|c|c|}
\hline Household Type & $\begin{array}{c}\text { (a) } \\
\text { Population } \\
\text { Change } \\
\text { 1990-2000 }\end{array}$ & $\begin{array}{c}\text { (b) } \\
\begin{array}{c}\text { Percent } \\
\text { of } \\
\text { Households }\end{array}\end{array}$ & $\begin{array}{c}\text { (c) } \\
\left(a^{*} b\right) \\
\text { Population } \\
\text { in } \\
\text { Subcategory }\end{array}$ & $\begin{array}{c}\text { (d) } \\
\text { People } \\
\text { per } \\
\text { Household }\end{array}$ & $\begin{array}{c}\qquad(e) \\
\qquad(c \div d) \\
\text { Household } \\
\text { Formation }\end{array}$ \\
\hline \multicolumn{6}{|c|}{ Young Adult Household Formation (25-34 age cohort) ${ }^{* *}$} \\
\hline Married Couple & 34,825 & 53 & 18,457 & 2.00 & 9,229 \\
\hline Single Person/Single Parent & 34,825 & 20 & 6,965 & 1.00 & 6,965 \\
\hline Two + Person & 34,825 & 14 & 4,876 & 2.29 & 2,129 \\
\hline Child of Householder & 34,825 & 13 & 4,527 & 0.00 & 0 \\
\hline Subtotal & & 100 & 34,825 & & 18,323 \\
\hline $\begin{array}{l}\text { Child of Householder } \\
\text { (35-44 lag effect) }\end{array}$ & 4,986 & 100 & 4,986 & 1.82 & 2,740 \\
\hline Total & & & & & 21,063 \\
\hline \multicolumn{6}{|c|}{ Net Immigrant Household Formation } \\
\hline Skılled & 9,250 & 15 & 1,400 & 2.25 & 622 \\
\hline Reunify Families & 9,250 & 17 & 1,600 & 4.00 & 400 \\
\hline Other & 9,250 & 44 & 4,000 & 3.38 & 1,183 \\
\hline Illegal & 9,250 & 24 & 2,250 & 5.00 & 450 \\
\hline Subtotal & & 100 & 9,250 & & 2,655 \\
\hline Nuclear Family (lag effect) & & & & & 297 \\
\hline Total & & & & & 2,952 \\
\hline \multicolumn{6}{|c|}{ Reductions in Households from Death } \\
\hline Live Alone & $(21,630)$ & 25 & $(5,408)$ & 1.00 & $(5,408)$ \\
\hline Live with Spouse & $(21,630)$ & 63 & $(13,626)$ & 2.00 & $(6,813)$ \\
\hline Live with Others & $(21,630)$ & 12 & $(2,596)$ & 0.00 & 0 \\
\hline Total & & 100 & $(21,630)$ & & $(12,221)$ \\
\hline Net Household Formation & & & & & 11,794 \\
\hline
\end{tabular}

*Columns (a), (c) and (d) are in thousands.

**People per household for the U.S. residents in the 25-34 age cohort only includes those people in that age cohort, not their offspring and other non-cohort individuals. 
be estimated using the weighted average of the other household types. Dividing the household type population (column c) by the population per household (column d) in Exhibit 7, we estimate household formation by the young adult cohort to be $21,063,000$ during the decade of the 1990s.

Net immigration to the United States will also increase household formation over the decade of the 1990s. From Exhibit 3, the net legal and illegal immigration to the U.S. is expected to be $9,250,000$ people during the 1990s. Using the immigration quotas from the Immigration Act of 1990, census data on immigration (summarized in Exhibit 2), and research by Edmonston and Passel (1992), Exhibit 7, subdivides net immigration to the U.S. into four categories: skill-based employer-sponsored, reunify families, illegal and other. During the 1990 s, the population of skilled-worker immigrants is expected to increase by $1,400,000$ people, while family reunifications and other immigration are expected to increase the population by $1,600,000$ and $4,000,000$ respectively. Illegal immigration to the U.S. is expected to expand the population by $2,250,000$ people in the decade. Some of the illegal immigrants and tightly housed legal immigrants are expected to move out of group housing and into nuclear family housing, creating additional housing demand (see the Nuclear Family lag effect category in Exhibit 7).

Population per household, column (d) of Exhibit 7, for immigrant households varies widely. From Carliner (1990), skill-based, employer-sponsored immigrants have an average household size of approximately 2.25. Population per household for family reunification is thinly discussed in the literature. Our best estimate of average population per household is 4.00 . Average household size for the "other" category is 3.38 , which uses the average size of a Hispanic household. Household size for illegal immigrants varies widely and little data is available on this segment of the immigrant population. Our best estimate is 5.00 population per household for illegal immigrant households. The estimated effects of net immigration to the U.S. between 1990 and 2000 will be an increase of 2,952,000 households.

Increases in net household formation must also be adjusted for the decrease in households from death. From the information presented in the previous section, the decrease in the number of households in the 1990s from death is expected to be 12.2 million households (see column (e) of Exhibit 7). In total, net household formation from Exhibit 7 , which includes increases in household formation from young person and immigrant households, and reductions in households from the death of elderly person households is projected to be an increase of 11.8 million households between years 1990-2000.

\section{Household Income and Housing Tenure}

The dream of homeownership is alive in the minds of Americans. According to the National Association of Realtors (October 1992), 93\% of renters in the 25-34 age cohort find homeownership at least somewhat important and $76 \%$ find homeownership "quite" or "extremely" important. Although homeownership may be of importance to many first-time homebuyers, income impediments may delay, or worse, make homeownership unattainable for many young adults.

To estimate owner-occupied versus renter-occupied housing demand in the United States, impediments to homeownership must be analyzed. In this section, we assess household income and household wealth in estimating demand for owner-occupied and renter-occupied units for the $1990 \mathrm{~s}$. 


\section{Household Income}

Virtually all first-time homeowners must borrow money to purchase a house. Lenders assess three primary attributes when underwriting an owner-occupied loan: household income, downpayment source and credit history. Both credit history and downpayment are of importance to the lender in underwriting an owner-occupied loan, but it is the borrower's ability to meet monthly debt service payments that is of primary concern. Maximum monthly debt service payments are based on household income.

Real median household income for the 25-34-year-old age cohort has been relatively stagnant since the U.S. Bureau of the Census first started collecting income by age cohort data in 1967. Exhibit 8 shows real median household income for the 25-34-year-old cohort generally growing from 1967-1973. After 1973, real median household income for this age group remains relatively flat through 1989 when it begins to fall from $\$ 33,743$ to $\$ 31,434$ in 1992 .

Disaggregating median household income by type of household is also instructive. Exhibit 9 depicts real median household income between 1980-1992 for married couple households, single parent female households, and non-family households. Median household income for married couple households between 1980 and 1992 maintained a real increase of $7 \%$. The 1992 married couple median household income was $\$ 42,140 .{ }^{21}$ Single parent female household income was $\$ 18,587$ in 1992 and grew less than $1 \%$ in the

\section{Exhibit 8 \\ Median Household Income for Young Adults in the United States, 1967-1992 (in 1992 dollars)}

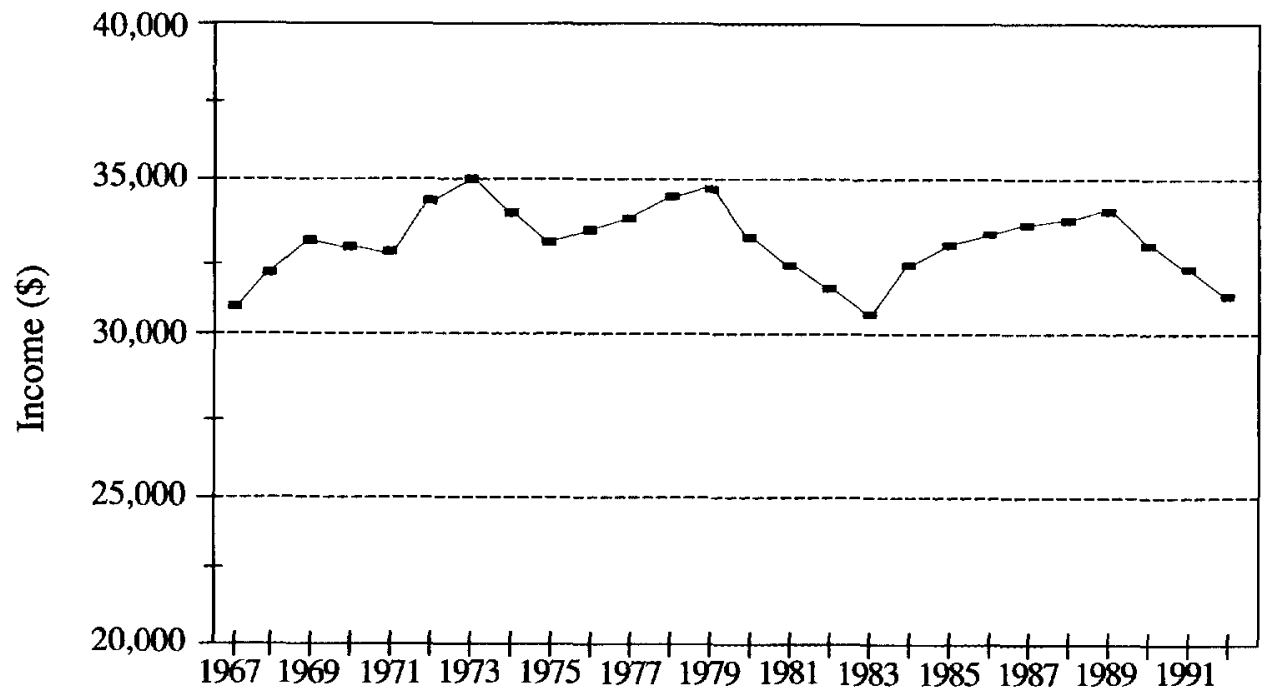

Source: U.S. Bureau of the Census (September 1993) 
1980-1992 period. ${ }^{22}$ Non-family household income increased $10 \%$ between $1980-1992$, and in 1992 was $\$ 17,711^{23}$

Expected changes in real household income in the 1990s are difficult to project. Easterlin (1980) suggests that individuals in large cohorts (e.g., baby boom generation) face stiffer competition in the labor market, thus reducing real household income gains. On the other hand, individuals in small cohorts (e.g., Generation X) have an easier time finding well-paying jobs and affordable housing. Generally speaking, large increases in the labor supply negatively impact real wages and small increases positively impact real wages; thus the first-time entries into the labor market during the 1990s should realize real wage increases.

Paradoxically, much of the expected real increase in median household income from a tighter supply of U.S. workers is expected to be offset by a worldwide surplus of workers. As U.S. corporations continue to restructure and displace workers in the 1990s, continued downward pressure will be put on household income, especially for the young workers attempting to compete with more experienced displaced employees. The results of corporate restructuring can be seen in Exhibit 9; real wages have fallen across all household types since 1989. Particularly hard hit by the reduction in real median income are non-family households with an $8.5 \%$ decline and single parent female households with a $5.5 \%$ decline in the $1989-1992$ period. Declines of this magnitude often take five years or more to recapture, making it unlikely that median household income for the

Exhibit 9

Median Household Income by Household Type, 1980-1992 (in 1992 dollars)

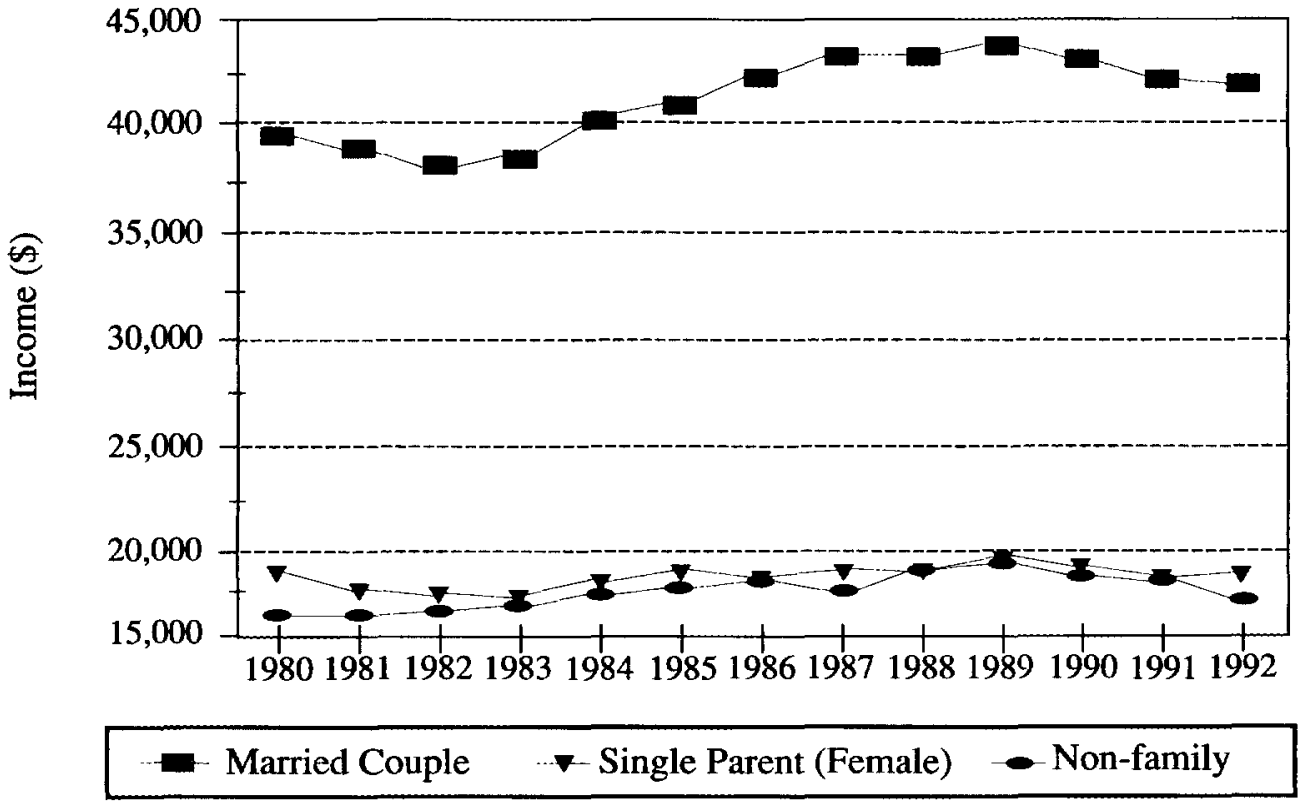

Source: U.S. Bureau of the Census (September 1993) 
25-34-year-old age cohort will maintain significant increases in real median income over the decade of the 1990 s.

Low wage rates also affect immigrants to the United States. According to the U.S. Bureau of the Census, immigrants who entered the U.S. between 1987-1990 had an average household income in 1989 dollars of $\$ 19,600 .{ }^{24}$

\section{Household Wealth}

To qualify for housing debt, potential homeowners must accumulate a downpayment. The income impediments to homeownership discussed in the prior section, also create impediments to savings and wealth accumulation. The 1990-1992 savings rate of $4.5 \%$ of disposable income is approximately $60 \%$ the 1980 savings rate of $7.1 \%$ (see Exhibit 10). The difficulty accumulating wealth for young renters is particularly acute. According to The Joint Center for Housing Studies (1993), median net wealth for all households in the $25-34$ age cohort is $\$ 2,096$, with only $25 \%$ of all young renter households able to cover the $15 \%$ downpayment and closing costs required to purchase the median valued house purchased by a first-time homebuyer.

\section{Housing Tenure}

Housing tenure in the United States in the 1990s is estimated in Exhibit 11 using homeownership rates disaggregated by type of household. Column (a) of Exhibit 11,

\section{Exhibit 10 \\ Personal Savings Rate as a Percent of Disposable Household Income}

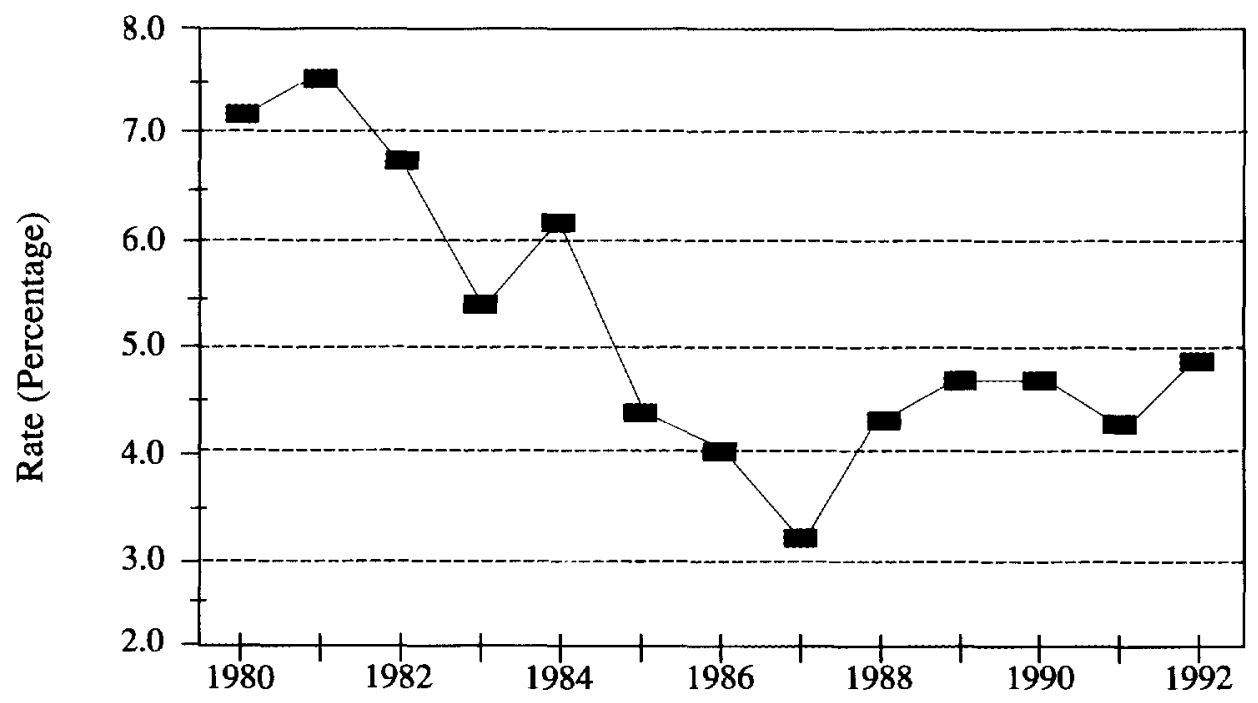

Source: The Tax Foundation (1992) 


\section{Exhibit 11 \\ Housing Demand in the United States, 1990-2000*}

\begin{tabular}{|c|c|c|c|c|}
\hline Household Type & $\begin{array}{l}\text { Number of } \\
\text { Households }\end{array}$ & $\begin{array}{c}\text { Homeownership } \\
\text { Rate }\end{array}$ & $\begin{array}{c}\langle c\rangle \\
\left\langle a^{*} b\right\rangle \\
\text { Owner- } \\
\text { Occupied } \\
\text { Demand }\end{array}$ & $\begin{array}{c}\text { (d) } \\
(a-c) \\
\text { Renter- } \\
\text { Occupied } \\
\text { Demand }\end{array}$ \\
\hline \multicolumn{5}{|c|}{ Young Adult Housing Demand (25-34 age cohort) } \\
\hline Married Couple & 9,229 & .576 & 5,316 & 3,913 \\
\hline Single Person/Single Parent & 6,965 & .243 & 1,692 & 5,273 \\
\hline Two + Person & 2,129 & .281 & 598 & 1,531 \\
\hline $\begin{array}{l}\text { Child of Householder } \\
\text { (35-44 lag effect) }\end{array}$ & 2,740 & .452 & 1,238 & 1,502 \\
\hline $\begin{array}{l}\text { Total Housing Demand for } \\
\text { the 25-34 Age Cohort }\end{array}$ & & & 8,844 & 12,219 \\
\hline \multicolumn{5}{|c|}{ Net Immigration Housing Demand } \\
\hline Skilled & 622 & .641 & 399 & 223 \\
\hline Reunify Families & 400 & .230 & 92 & 308 \\
\hline Other & 1,183 & .230 & 272 & 911 \\
\hline Illegal & 450 & .000 & 0 & 450 \\
\hline Nuclear Family (lag effect) & 297 & .230 & 68 & 229 \\
\hline Total Immigrant Housing Den & & & 831 & 2,121 \\
\hline \multicolumn{5}{|l|}{ Shifts in Housing Demand** } \\
\hline 35-44 Age Cohort & 20,323 & .230 & 4,674 & $(4,674)$ \\
\hline 45-54 Age Cohort & 21,304 & .116 & 2,471 & $(2,471)$ \\
\hline Immigration (1971-80) & 1,329 & .210 & 279 & $(279)$ \\
\hline Immigration (1981-90) & 2,171 & .210 & 456 & $(456)$ \\
\hline Total Housing Demand Shift & & & 7,880 & $(7,880)$ \\
\hline \multicolumn{5}{|c|}{ Decreased Housing Demand from Death } \\
\hline Housing Vacancies & $(12,221)$ & .773 & $(9,447)$ & $(2,774)$ \\
\hline $\begin{array}{l}\text { Net Housing Units Demandec } \\
1990-2000\end{array}$ & & & 8,108 & 3,686 \\
\hline
\end{tabular}

*Columns (a), (c) and (d) are in thousands.

**The homeownership rate, column (b), represents the change in ownership rates between age cohorts. Homeownership rates stabilize after the $45-54$ age cohort.

household formation during the 1990s, is derived from the results of Exhibit 7 . Homeownership rates depicted in column (b) of Exhibit 11 are based on findings of The Joint Center for Housing Studies (1993). Homeownership rates are expected to remain stable during the decade, even in the face of stagnant real incomes (see Exhibits 8 and 9) and low savings rates (see Exhibit 10). The primary reason for not reducing the rate of homeownership by household type is because of recent initiatives by both FNMA and FHLMC allowing for a lower downpayment and providing a wide range of mortgage 
instruments for low to moderate income home purchasers. Although, it should be noted, that because of shifts in household type, overall, homeownership rates decline for the 25-34 age cohort.

Homeownership rates for the Net Immigration Housing Demand subsection in Exhibit 11 vary widely. First, homeownership for the skilled worker category is expected to reflect the average homeownership rate in the U.S. of $64.1 \%$, which is generally consistent with Carliner (1990). The $23 \%$ homeownership rate for the other immigrant categories is based on the homeownership rates for new immigrants arriving in the past ten years. ${ }^{25}$ Additionally, it was assumed that all illegal immigrants rent, as the income and credit history of illegal immigrants is difficult to verify for mortgage underwriting.

As younger cohorts age, the type of housing they demand changes. Homeownership rates increase as households increase in age and are highest for the 45-54 age cohort. The Shifts in Housing Demand subsection of Exhibit 11, addresses higher homeownership rates among older age cohorts. The percent of owner-occupied households increases to $65.5 \%$ in the $35-44$ age cohort and then stabilizes at $77 \%$ for the $45-54$ age cohorts and older. The change in the rate of homeownership between the 25-34 and $35-44$ age cohorts is $23.0 \%(65.5-42.5 \%)$. Similarly, the change in ownership rates between the $35-44$ and $45-54$ age cohorts is $11.6 \%(77.1 \%-65.5 \%)$.

Shifts in housing demand also occur in the foreign-born population. Although only $23 \%$ of new immigrant households purchase a house upon arrival in the U.S., $65 \%$ of the foreign-born householders are homeowners after living in the United States for twenty years. ${ }^{26}$ These increases in homeownership rates are adjusted for using a ten-year and a twenty-year lag factor.

Increases in the demand for renter-occupied and owner-occupied housing must be reduced by additions to the supply from the death of householders. During the 1990 s approximately 12.22 million housing units will become available from the death of a householder, of which $77.3 \%$ are owner-occupied units.

From Exhibit 11,8.11 million new owner-occupied housing units and 3.69 million new renter-occupied units will be demanded in the 1990s. Estimated housing demand from 25-35-year-old households accounts for 8.84 million owner-occupied and 12.22 million renter-occupied units. The projected increase of 9.25 million immigrants to the United States will create an additional demand of 2.95 million housing units, .83 million owneroccupied units and 2.32 million renter-occupied units.

Homeownership rates increase with age through the 45-54 age cohort. To account for this increase in U.S.-born homeownership, a shift in demand out of renter-occupied units and into owner-occupied units totals 7.14 million households. Additionally, immigrants to the U.S. also are more prone to own than rent the longer they reside in the U.S. Approximately .74 million immigrants to the U.S. in the 1970 s and 1980 s are expected to move into owner-occupied housing from renter-occupied housing.

Lastly, additions to the housing supply from death are expected to decrease the need for additional housing by 9.4 million owner-occupied units and 2.8 million renteroccupied units. The net number of housing units demanded for the period 1990-2000 is expected to be 11.80 million units, of which 8.11 million are expected to be owneroccupied and 3.69 million are expected to be renter-occupied. ${ }^{27}$ 


\section{Conclusion}

We estimate the demand for housing in the 1990s by assessing trends in household formation. A higher portion of housing demand in the 1990 s will come from single person, single parent, and immigrant households, while the proportion of married couple household formations is expected to decline. The increase in demand for renter-occupied housing by the less well-to-do single person, single parent, and immigrant households is offset by the baby boom cohort shifting into owner-occupied housing.

Our findings indicate that household formations will average approximately 1.2 million per year during the $1990 \mathrm{~s}$, which is lower than the 1980 s annual rate of 1.5 million household formations and the 1970s annual rate of 1.7 million household formations. Owner-occupied demand in the 1990s is expected to average 811,000 units per year, a decline of 174,000 units per year from the prior decade's demand of 985,000 owneroccupied units. Multifamily housing demand is estimated to be 369,000 per year during the 1990s. This is a significant decline from the previous decade's average demand of 507,000 rental units.

\section{Notes}

${ }^{1}$ Real estate investment is based on a set of assumptions about the future. The better defined the set of assumptions, the more accurate the estimation of future cash flows, and value. Without the assistance of a well-defined market forecast over the entire holding period of a real estate asset, cash flow analyses become based on conjecture.

${ }^{2}$ For a review of the housing demographic literature see Burch (1979).

${ }^{3}$ See Myers (1987), Leppel (1991), Plane and Rogerson (1991), among others.

${ }^{4}$ Dunn (1993) defines Generation $X$ as all people born between 1965 and 1978. Generation X has also been referred to as the "baby-bust" generation.

${ }^{5}$ U.S. Bureau of the Census (May 1993).

${ }^{6}$ National Association of Realtors (September 1992).

${ }^{7}$ U.S. Bureau of the Census (1992).

${ }^{8}$ U.S. Bureau of the Census (1992).

${ }^{9}$ Moore (1991), p. 45.

${ }^{10}$ Moore (1991), p. 45.

"Edmonston and Passel (1992), p. 18.

${ }^{12}$ Edmonston and Passel (1992), p. 38.

${ }^{13}$ U.S. National Center for Health Statistics (annual).

${ }^{14}$ U.S. National Center for Health Statistics (annual).

${ }^{15}$ Young adult households are defined by the Joint Center for Housing Studies (1993) as the 25-34 age cohort.

${ }^{16}$ U.S. Bureau of the Census (1992).

${ }^{17}$ Increases in household size attributable to the offspring of the 25-34 age cohort do not affect the number of 25-34-year-old individuals per household and thus are not included in the population per household ratio.

${ }^{18}$ U.S. Bureau of the Census (1991).

${ }^{19}$ U.S. Bureau of the Census (January 1990).

${ }^{20}$ U.S. Bureau of the Census (1992).

${ }^{21}$ U.S. Bureau of the Census (September 1993).

${ }^{22}$ U.S. Bureau of the Census (1993).

${ }^{23}$ U.S. Bureau of the Census (1993). 
${ }^{24}$ Lapham (1994).

${ }^{25}$ Joint Center for Housing Studies (1993), p. 12.

${ }^{26}$ Joint Center for Housing Studies (1993), p. 12.

${ }^{27}$ The total demand for new housing units does not include the demand created by the removal of housing units. According to the National Association of Home Builders (1992), approximately 210,000 housing units will be demolished each year in the 1990s. Including the demolition of existing housing units, housing demand during the 1990s is approximately 1.39 million units per year.

\section{References}

Burch, T. K., Household and Family Demography: A Bibliographic Essay, Population Index, 1979 , $45,173-95$.

Carliner, M., Immigration: Demographic Wild Card, Housing Economics, March 1990, 4-8.

Childs, M. J., C. M. Rhoads and M. J. Eppli, Rental Housing Demand in the 1990s and Beyond, Real Estate Outlook, February 1993, 10-16.

Dunn, W., The Baby Bust. A Generation Comes of Age. Ithaca, N.Y.: American Demographics Books, 1993.

Easterlin, R., Birth and Fortune. The Impact of Numbers on Personal Welfare, New York: Basic Books, 1980.

Edmonston, B. and J. S. Passel, The Future Immigrant Population of the United States, Washington, D.C.: The Urban Institute, February 1992.

Information Please Almanac: 1994, New York: Houghton Mifflin Company, 1994.

Joint Center for Housing Studies, The State of the Nation's Housing, 1993, Cambridge, Mass.: Harvard University, 1993.

Lapham, S., Unpublished data by the U.S. Bureau of the Census, 1994.

Leppel, K., Demographic Effects on Household Formation Patterns, Journal of Real Estate Research, 1991, 6:2, 191-206.

Moore, S., Mixed Blessings, Across the Board, March 1991, 45-49.

Myers, D., Extended Forecasts of Housing Demand in Metropolitan Areas: The Coming Downturn, Appraisal Journal, April 1987, 266-78.

National Association of Home Builders, The Future of Home Bulding, Washington, D.C.: NAHB, 1992.

National Association of Realtors, Residential Finance Panel, Washington, D.C.: NAR, September 1992.

- Survey of Homeowners and Renters: Key Findings, Washington, D.C.: NAR, October 1992.

Plane, D. A. and P. A. Rogerson, Tracking the Baby Boom, The Baby Bust, and the Echo Generations: How Age Composition Regulates U.S. Migration, Professional Geographer, 1991, 43:4, 416-30.

Tax Foundation, Facts \& Figures on Government Finance: 1992, Washington, D.C.: Tax Foundation, 1992, 19.

U.S. Bureau of the Census, Current Population Reports, Household and Family Characteristics: March 1991, Ser. P-20, No. 458, March 1991.

Current Population Reports, Household and Family Characteristics: February 1992, Ser. P-20, No. 461, February 1992.

, Current Population Reports, Money Income of Households, Families, and Persons in the United States: 1992, Ser. P-60, No. 184, B-8, September 1993.

-.....-, Current Population Reports, Population Profile of the United States, 1993, Ser. P-23, No. 185, May 1993. 
Current Population Reports, Projections of the Population of the United States, by Age, Sex, and Race: 1989 to 2010, Ser. P-25, No. 1053, January 1990. , Statistical Abstract of the U.S., 1990, Table 60, 47.

U.S. National Center for Health Statistics, Vital Statistics of the United States, annual, Monthly Vital Statistics Report, and unpublished data.

An earlier version of this paper was published by M. J. Childs, C. M. Rhoads and M. J. Eppli, in Real Estate Outlook. The current version is completely rewritten and contains a more detailed analysis of housing demand and different analysis techniques. We would like to thank C. M. Rhoads for his data collection contributions to this paper. We are also grateful to J. D. Benjamin for his valuable editorial comments on a previous version of the paper. 